plus en avant cette identité «brésilo-africaine » au regard de travaux comme ceux de Peel sur l'identité yoruba qui s'est construite et, nous ne pensons pas que ce soit un hasard, à la même période. Une vision essentialiste de l'identité brésilienne de ces Retournés en Afrique parcourt l'ensemble du livre, même si l'auteur reconnaît que ces «Brésiliens» ne désignent pas uniquement des descendants de Retournés.

Septembre 2009, Kadya Tall

\title{
Jean-Pierre Dozon, Une anthropologie en mouvement : l'Afrique miroir du contemporain, Versailles, Éditions Quae, 2008272 p., ISBN : 978-2-7592- 0087-0.
}

In this volume, Jean-Pierre Dozon has brought together a number of articles he has published in the last thirty years. The ambition, above and beyond making them more widely available, is to reflect on the evolution of African Studies in France by means of his fieldwork experience. The author is well known for his work on Côte d'Ivoire, where he has done research since the seventies, and it is to this country that he returns time and time again in these articles. He has done fieldwork on agricultural development and on illness, which brings a wider framework to the detailed anthropology of the Bété region in Côte d'Ivoire, for which he is best known. This book is an attempt to bring this vast research experience to bear on the issue of what Africanist work entails and why it needs to be selfreflective.

The book is divided into four parts : one on ethnicity in its local context, which focuses on the author's fieldwork area in the Bété region; another on the experience of wet rice agriculture in Côte d'Ivoire; the third on health, including a history of French colonial efforts at fighting sleeping sickness and the more contemporary question of HIV/AIDS ; and the last on the origins and significance of prophetic cults in Côte d'Ivoire. There is no connection between these four parts but the author provides for each a short introduction that attempts to connect some of the questions raised in each part to the overall issue of Africanist scholarship.

Each part is interesting in itself and most, although not all, of the articles deserve re-publication. While some of the early articles are obviously dated in terms of the broadly Marxist approach taken, the author has always been careful to let the material speak for itself so that the interpretations provided are still of interest today. One will read with profit the discussion on ethnicity, belonging and identity in Côte d'Ivoire. Indeed, some of the pieces written before the civil war are quite prescient on the dangers facing the country as it began to tear itself apart through a crass instrumentalisation of identity.

But perhaps the two most interesting series of articles are those that concern the continuities and contrast between the colonial and post-colonial approaches to illness and the discussion of the politics of prophetic agitation. Here the author's historical knowledge and his knowledge of the terrain combine to offer the reader 
a subtle appreciation of questions that are all too often discussed in simplistic terms. And both are very relevant to the contemporary world.

Leaving aside the limitations of volumes of this ilk, such as repetition, it might have been useful to open and close the book with two specially-written essays on the obstacles faced by Africanist scholarship over the decades since independence. The concluding chapter as it stands (also a reprint) does not serve that purpose. This would have helped place the chapters in appropriate intellectual context and would have focused attention of how Africanist writing cannot but help being political. Nevertheless, this is a worthwhile addition to the literature both because it brings together some of Dozon's important articles and because it provides a useful point of entry for questions that are still relevant today.

June 2009, Patrick Chabal

Carlos M. Lopes, Roque Santeiro. Entre a Ficção e a Realidade, Estoril, Princípia Editora, 271 p., photos noir et blanc et couleur, 2007, ISBN : 978-9898131-01-0.

Cinq choses surprennent à propos de ce livre : $1^{\circ}$ ) le fait que je puisse en parler alors que, devant le silence de l'éditeur, sourd à toutes mes demandes de service de presse pour des titres antérieurs, j’avais renoncé depuis longtemps à écrire quoi que ce soit sur sa production ; $2^{\circ}$ ) qu'une banque, deux institutions officielles (une angolaise et une portugaise) et deux fondations portugaises ont financé sa publication, lorsque l'on sait qu'au moins trois d'entre elles ne répondent pas aux solliciteurs non introduits; $3^{\circ}$ ) l'originalité du thème traité par l'auteur puisque sous couvert d'une étude socio-économique sérieuse, il a élevé en fait un monument à l'initiative individuelle, l'antithèse de ce que prétendaient vouloir créer les fondateurs du nationalisme angolais actuellement au pouvoir ; $4^{\circ}$ ) la hardiesse, l'habilité ou l'entregent de ce même auteur qui a su - ou pu - faire fondre en sa faveur les icebergs bureaucratiques précédemment évoqués; $5^{\circ}$ ) la maîtrise dont il a fait preuve pour mener son travail à bien dans un environnement pour le moins difficile.

De quoi s'agit-il? De la description et de l'analyse lexicale, micro-économique, sociologique et administrative du plus grand bazar de la débrouillardise d'Afrique centrale, à la fois insurpassable marché aux voleurs et aux petites combines de Luanda, centre de redistribution pour bourses plates ou bien garnies, et temple suprême de la survie dans une mégapole anarchique et ingérable, abandonnée aux démons de tous les trafiquants, grandissimes ou squelettiques. Les premiers sont dénoncés parfois par quelques littérateurs locaux, mais encore lucides, les autres excusés ou secourus par de bonnes âmes, mais étrangères. Certains veulent voir dans cette victoire de la libre entreprise débridée, à ciel ouvert, un exemple de la vitalité et de la créativité de millions d'Angolais plongés dans des conditions de vie infra ou inhumaines. Certes et c'est flatteur pour les survivants. D'autres estiment que c'est tout aussi bien le symbole désespéré d'une colossale faillite des «élites» de tous les horizons politiques incapables d'assurer à «leur» peuple, 